\title{
Severe Hypocalcemia Following Spontaneous Abortion in a Renal Transplant Patient
}

\author{
Lerman $\mathbf{M} \mathbf{J}^{\mathbf{1}}$ and Aronoff $\mathbf{R}^{\mathbf{2}}$
}

${ }^{1}$ Renal Transplantation, Medical City, Dallas, Texas, USA

${ }^{2}$ Surgery, Medical City, Dallas, Texas, USA

\begin{abstract}
Parathyroid hormone like hormone has been found in fetal tissues/placenta during pregnancy. Increased levels of calcitriol have also been found in pregnant women. We recently followed a renal transplant patient who developed hypercalcemia during pregnancy with significantly elevated parathyroid hormone levels. Subtotal parathyroidectomy did not lead to hypocalcemia until she had a spontaneous abortion several months later.
\end{abstract}

Keywords: Parathyroid hormone; Hypercalcemia; Hormone; Creatinine

\section{Introduction}

Patient presented to the hospital with hypercalcemia, acute renal insufficiency, and was also pregnant with a first term fetus. This 39-year-old African American woman was 2 years post a deceased donor kidney transplant. The serum calcium was $12.2 \mathrm{mg} / \mathrm{dl}$, albumin $2.8 \mathrm{gm} / \mathrm{dl}$, phosphorus $2.3 \mathrm{mg} / \mathrm{dl}$, alkaline phosphatase $80 \mathrm{Units} / \mathrm{LS}$ and serum creatinine $4.9 \mathrm{mg} / \mathrm{dl}$. Intact PTH was $395 \mathrm{pg} / \mathrm{ml}$, serum protein electrophoresis was normal, qualitative serum HCG was positive, and transvaginal ultrasound revealed a single intrauterine fetus approximately 6 weeks and 6 days by age with viability. Following IV hydration with normal saline, the patient underwent a subtotal parathyroidectomy. There were no postoperative complications to either the patient or the pregnancy. The serum calcium decreased to 8.9 $\mathrm{mg} / \mathrm{dl}$, serum creatinine decreased to $1.3 \mathrm{mg} / \mathrm{dl}$, and PTH to $42 \mathrm{pg} / \mathrm{ml}$. Remarkably, the patient did not require any post-operative calcium or vitamin D supplementation to prevent hypocalcemia following subtotal PTX $[1,2]$. This patient chose to attempt to carry the pregnancy to term. Fetal maternal medicine was consulted and medications were adjusted to avoid any potentially teratogenic medications. She was switched from tacrolimus to cyclosporine and from mycophenolate to azathioprine. She continued to be followed closely as a high risk pregnancy. 3 months following her parathyroidectomy she had a serum creatinine of 1.37 $\mathrm{mg} / \mathrm{dl}$, a serum calcium of $8.5 \mathrm{mg} / \mathrm{dl}$, and continued to not require any vitamin $\mathrm{D}$ or calcium supplements. 2 weeks later, patient was admitted to a local emergency room with a spontaneous abortion. She was seen in the transplant clinic for follow up approximately 2 weeks later and was noted to have serum calcium of $6 \mathrm{mg} / \mathrm{dl}$, serum albumin of $3 \mathrm{gm} / \mathrm{dl}$, creatinine of $2 \mathrm{mg} / \mathrm{dl}$ and intact PTH level of $80 \mathrm{pg} / \mathrm{ml}$. She was started on calcitriol $0.5 \mathrm{mcg}$ b.i.d. and calcium carbonate 2 g every 6 hours. A transplant allograft biopsy was done which revealed no evidence of rejection only some mild tubular injury. The cyclosporine level was moderately elevated at $250 \mathrm{ng} / \mathrm{ml}$. Serum calcium improved to about $7.5 \mathrm{mg} / \mathrm{dl}$, creatinine returned to baseline, and she was discharged in stable condition (Figure 1).

\section{Discussion}

The cause of hyperparathyroidism in our patient was felt to be due to hyperplasia of all four parathyroid glands. The surgical histopathology revealed hyperplastic parathyroid tissue with dystrophic calcifications involving the left superior parathyroid $(0.75$ g), right superior parathyroid (0.99 g), right inferior parathyroid (0.29 $\mathrm{g})$, left inferior parathyroid ( $1.24 \mathrm{~g})$. We do not believe our patient had any ectopic parathyroid glands, as the decrease in serum PTH levels was greater than $70 \%$ after surgery. The majority of patients with severe hyperparathyroidism develop significant hypocalcemia usually within several hours following total or subtotal parathyroidectomy. The mechanism for post-surgical hypocalcemia is decrease bone reabsorption and increased bone formation "hungry bone syndrome" [3]. The failure to develop hypocalcemia in our patient after removing the majority of parathyroid tissue is not well explained. Circulating biologically active parathyroid hormone was markedly decreased following surgery. Vitamin D and calcium supplements were not necessary until fetal/placental tissues were no longer present.

We believe fetal tissues/placenta in this case must have been producing a significant amount of biologically active parathyroid hormone, parathyroid hormone like hormone [4], or vitamin D. Once the pregnancy prematurely ended, significant hypocalcemia developed. It would be very unusual for patients with severe diffuse parathyroid hyperplasia to not develop post parathyroidectomy hypocalcemia

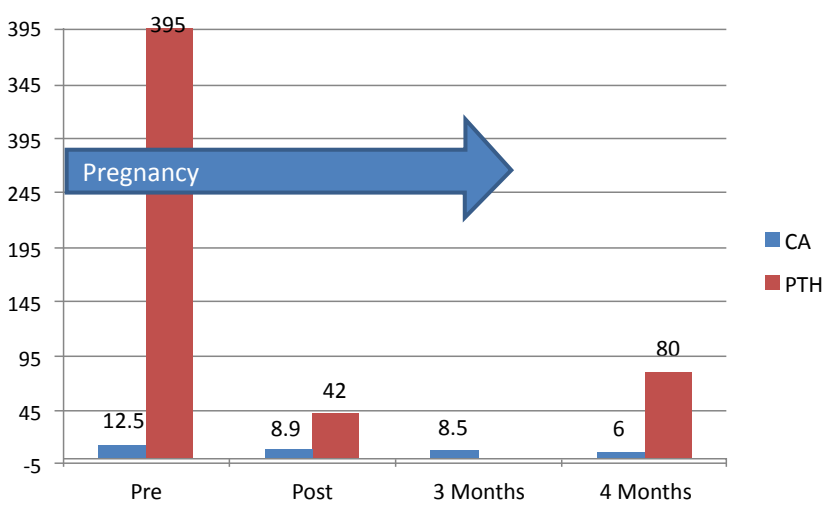

Figure 1: Represents variation in the level of Parathyroid harmone and Creatinine at different level of pregnancy.

*Corresponding author: Lerman MJ, Renal Transplantation, Medical City, Dallas, Texas, USA, Tel: 2148024006; E-mail: lermanm@dneph.com.com

Received May 04, 2016; Accepted May 11, 2016; Published May 21, 2016

Citation: Lerman MJ, Aronoff R (2016) Severe Hypocalcemia Following Spontaneous Abortion in a Renal Transplant Patient. Med Rep Case Stud 1: 115. doi: 10.4172/2572-5130.1000115

Copyright: (c) 2016 Lerman MJ, et al. This is an open-access article distributed under the terms of the Creative Commons Attribution License, which permits unrestricted use, distribution, and reproduction in any medium, provided the original author and source are credited. 
Citation: Lerman MJ, Aronoff R (2016) Severe Hypocalcemia Following Spontaneous Abortion in a Renal Transplant Patient. Med Rep Case Stud 1: 115. doi: $10.4172 / 2572-5130.1000115$

Page 2 of 2

almost immediately after surgery. The mild increase in PTH from 42 to $80 \mathrm{pg} / \mathrm{ml}$ after abortion could be explained by the much lower serum calcium level. Hypocalcaemia can increase PTH production and release from the remaining (less than $2 / 3$ ) parathyroid gland. Late hypocalcaemia with normal PTH levels due to other causes would be far less likely [5]. This begs the question what was protecting our patient from hypocalcaemia following surgery while pregnant?

\section{References}

1. Guo L, Shu-Tao Q, De-Quiang M, De-Qiang M, Xing-Wei L, et al. (2012) The roles of parathyroid hormone-like hormone during mouse preimplantation embryonic development. Plus One 7: 1-10.
2. O'Brien KO, Li S, Cao C, Kent T, Young BV, et al. (2014) Placental CYP27B1 and CYP24A1 expression in human placental tissue and their association with maternal and neonatal calcitropic hormones. J Clin Endocrinol Metab 99: 1348-1356.

3. Brasier AR, Nussbaum SR (1988) Hungry bone syndrome: clinical and biochemical predictors of its occurrence after parathyroid surgery. Am J Med 84: 654-660.

4. Eller-Vainicher C, Ossola M, Beck-Peccoz P, Chiodina I (2012) PTHrPassociated hypercalcemia of pregnancy resolved after delivery: a case report. Eur J Endocrinol 166: 753-756.

5. Thakker RV (2006) Hypocalcaemia: Pathogenesis, differential diagnosis, and management (6th edn.). American Society of Bone and Mineral Research. 